\section{Microbially Enhanced Carbon Capture and Storage by Mineral-Trapping and Solubility-Trapping}

\author{
A N D REW C. M I T C H E L L , ${ }^{*}, \dagger, \$$ \\ KNUD DIDERIKSEN, ${ }^{\circledR}$ LEE H. SPANGLER, \\ ALFRED B. CUNNINGHAM,$^{\dagger}$ AND \\ ROBIN GERLACH ${ }^{\dagger}$ \\ Center for Biofilm Engineering, Montana State University, \\ Bozeman, Montana, 59717, Department of Chemistry and \\ Biochemistry, Montana State University, Bozeman, Montana, \\ 59717, and NanoGeoScience Group, Nano-Science Center, \\ Department of Chemistry, University of Copenhagen, \\ DK-2100 Copenhagen Ø, Denmark
}

Received November 4, 2009. Revised manuscript received March 24, 2010. Accepted April 6, 2010.

The potential of microorganisms for enhancing carbon capture and storage (CCS) via mineral-trapping (where dissolved $\mathrm{CO}_{2}$ is precipitated in carbonate minerals) and solubility trapping (as dissolved carbonate species in solution) was investigated. The bacterial hydrolysis of urea (ureolysis) was investigated in microcosms including synthetic brine (SB) mimicking a prospective deep subsurface CCS site with variable headspace pressures $\left[p\left(\mathrm{CO}_{2}\right)\right]$ of ${ }^{13} \mathrm{C}-\mathrm{CO}_{2}$. Dissolved $\mathrm{Ca}^{2+}$ in the $\mathrm{SB}$ was completely precipitated as calcite during microbially induced hydrolysis of $5-20 \mathrm{~g} \mathrm{~L}^{-1}$ urea. The incorporation of carbonate ions from ${ }^{13} \mathrm{C}-\mathrm{CO}_{2}\left({ }^{13} \mathrm{C}-\mathrm{CO}_{3}{ }^{2-}\right)$ into calcite increased with increasing $\mathrm{p}\left({ }^{13} \mathrm{CO}_{2}\right)$ and increasing urea concentrations: from $8.3 \%$ of total carbon in $\mathrm{CaCO}_{3}$ at $1 \mathrm{~g} \mathrm{~L}^{-1}$ to $31 \%$ at $5 \mathrm{~g} \mathrm{~L}^{-1}$, and $37 \%$ at $20 \mathrm{~g} \mathrm{~L}^{-1}$. This demonstrated that ureolysis was effective at precipitating initially gaseous $\left[\mathrm{CO}_{2}(\mathrm{~g})\right]$ originating from the headspace over the brine. Modeling the change in brine chemistry and carbonate precipitation after equilibration with the initial $\mathrm{p}\left(\mathrm{CO}_{2}\right)$ demonstrated that no net precipitation of $\mathrm{CO}_{2}(\mathrm{~g})$ via mineral-trapping occurred, since urea hydrolysis results in the production of dissolved inorganic carbon. However, the $\mathrm{pH}$ increase induced by bacterial ureolysis generated a net flux of $\mathrm{CO}_{2}(\mathrm{~g})$ into the brine. This reduced the headspace concentration of $\mathrm{CO}_{2}$ by up to $32 \mathrm{mM}$ per $100 \mathrm{mM}$ urea hydrolyzed because the capacity of the brine for carbonate ions was increased, thus enhancing the solubility-trapping capacity of the brine. Together with the previously demonstrated permeability reduction of rock cores at high pressure by microbial biofilms and resilience of biofilms to supercritical $\mathrm{CO}_{2}$, this suggests that engineered biomineralizing biofilms may enhance CCS via solubility-trapping, mineral formation, and $\mathrm{CO}_{2}(\mathrm{~g})$ leakage reduction.

\footnotetext{
* Corresponding author e-mail: andrew.mitchell@erc.montana. edu.

${ }^{\dagger}$ Center for Biofilm Engineering, Montana State University.

${ }^{\S}$ University of Copenhagen.

‡ Department of Chemistry and Biochemistry, Montana State University.
}

\section{Introduction}

Geologic sequestration of carbon dioxide, also known as carbon capture and storage (CCS), is one strategy to reduce the emission of greenhouse gases generated through the combustion of fossil fuels. Geologic sequestration of $\mathrm{CO}_{2}$ involves the injection of supercritical $\mathrm{CO}_{2}\left(\mathrm{SC}-\mathrm{CO}_{2}\right.$; critical point $=31.1{ }^{\circ} \mathrm{C}$ and $73 \mathrm{~atm}$ ) into underground formations such as oil bearing formations, deep unmineable coal seams, and deep saline aquifers $(1,2)$. Methods that can trap $\mathrm{CO}_{2}$ in a nonlabile phase would be advantageous in the development of subsurface $\mathrm{CO}_{2}$ storage as a viable engineered mechanism to reduce the net emission of $\mathrm{CO}_{2}$ from fossil fuel combustion (2-5). This includes so-called mineraltrapping, where carbonate ions from the injected $\mathrm{CO}_{2}$ can be incorporated into a solid carbonate mineral, and solubilitytrapping, where aqueous inorganic carbon species are contained in the formation water itself (6). SC $-\mathrm{CO}_{2}$ injection into deep underground formations can result in elevated pressure in the region surrounding the point of injection. As a result, an upward hydrodynamic pressure gradient may develop across the trapping cap-rock, leading to the upward leakage of $\mathrm{CO}_{2}$, due to the primary permeability of the caprock, through fractures, or near injection wells (2). Therefore, methods that can simultaneously reduce such leakage and facilitate trapping $\mathrm{CO}_{2}$ in nonlabile forms would be advantageous. Calcium is the most abundant cation in many surfaceand ground-waters ( 7 ) and therefore mineralization in $\mathrm{CaCO}_{3}$, a common rock forming mineral, may provide an effective means of immobilization during mineral-trapping. Equally, amendments to brine chemistry may enhance the capacity of the brine for $\mathrm{CO}_{2}(\mathrm{~g})$ and dissolved carbonate ions, thus increasing the solubility-trapping capabilities.

Laboratory and field studies into $\mathrm{SC}-\mathrm{CO}_{2}$-fluid-rock interactions are limited, but general processes have been investigated for injection into brine formations (8). Injection of $\mathrm{SC}-\mathrm{CO}_{2}$ into brine aquifers initially reduces the $\mathrm{pH}$ of the brine by $1.5-4 \mathrm{pH}$ units due to the dissolution of $\mathrm{CO}_{2}$ and disassociation of $\mathrm{H}_{2} \mathrm{CO}_{3}$ (eqs 1-4) (7) depending on the brine chemistry, formation lithology, and temperature (9). However, carbonate alkalinity is also produced by the reaction of $\mathrm{H}_{2} \mathrm{CO}_{3}$ with reservoir minerals (8-10), and computational and laboratory experiments suggest that overall, $\mathrm{pH}$ actually increases by around 0.5 to 1 units relative to the preinjection brine (9).

Mineralization of injected $\mathrm{CO}_{2}$ into $\mathrm{CaCO}_{3}$ will be possible if the equilibrium of the reaction $\mathrm{Ca}^{2+}+\mathrm{CO}_{3}{ }^{2-} \Leftrightarrow \mathrm{CaCO}_{3}$ can be moved to the right and the saturation state of $\mathrm{CaCO}_{3}$ is exceeded. This may be achievable if sufficient dissolved $\mathrm{Ca}$ is present, if $\mathrm{pH}$ and alkalinity can be increased, and if appropriate nucleation substrates are present (7). Microbiologically enhanced $\mathrm{CaCO}_{3}$ precipitation offers a potential mechanism to achieve this in situ. Microbes have been shown to enhance $\mathrm{CaCO}_{3}$ precipitation via cation adsorption to negatively charged functional groups on microbe surfaces and by metabolically driven changes in the solution chemistry, which increase mineral saturation and induce nucleation (11). An increase in $\mathrm{pH}, \mathrm{CO}_{3}{ }^{2-}$, and $\mathrm{HCO}_{3}{ }^{-}$can be caused for instance by bacterial ureolysis (the enzymatic hydrolysis of urea) (12), sulfate, iron, or nitrate reduction $(13,14)$, or alkalization during photosynthesis (15). In subsurface environments, $\mathrm{CaCO}_{3}$ precipitation induced by the ureolysis of injected urea has been investigated as a potential method to reduce bedrock porosity for enhanced oil recovery (16) and for coprecipitating radionuclides from groundwater in the vadose zone of contaminated aquifers $(12,17-19)$. 
Ureolysis results in the production of ammonium $\left(\mathrm{NH}_{4}^{+}\right)$, dissolved inorganic carbon (DIC), and an increase in $\mathrm{pH}$ via a net production of $\mathrm{OH}^{-}$ions (eqs 5-9), which favors $\mathrm{CaCO}_{3}$ precipitation (eqs 10 and 11).

$\mathrm{CO}_{2}$ (g) Dissolution and Disassociation.

$$
\begin{gathered}
\mathrm{CO}_{2}(\mathrm{~g}) \leftrightarrow \mathrm{CO}_{2}(\mathrm{aq}) \\
\mathrm{CO}_{2}(\mathrm{aq})+\mathrm{H}_{2} \mathrm{O}(\mathrm{l}) \leftrightarrow \mathrm{H}_{2} \mathrm{CO}_{3} \\
\mathrm{H}_{2} \mathrm{CO}_{3} \leftrightarrow \mathrm{HCO}_{3}^{-}+\mathrm{H}^{+} \\
\mathrm{HCO}_{3}^{-} \leftrightarrow \mathrm{CO}_{3}^{2-}+\mathrm{H}^{+}
\end{gathered}
$$

Ureolysis.

$$
\begin{gathered}
\mathrm{CO}\left(\mathrm{NH}_{2}\right)_{2}+\mathrm{H}_{2} \mathrm{O} \rightarrow \mathrm{NH}_{2} \mathrm{COOH}+\mathrm{NH}_{3} \\
\mathrm{NH}_{2} \mathrm{COOH}+\mathrm{H}_{2} \mathrm{O} \rightarrow \mathrm{NH}_{3}+\mathrm{H}_{2} \mathrm{CO}_{3} \\
\mathrm{H}_{2} \mathrm{CO}_{3} \leftrightarrow \mathrm{HCO}_{3}^{-}+\mathrm{H}^{+} \\
2 \mathrm{NH}_{3}+2 \mathrm{H}_{2} \mathrm{O} \leftrightarrow 2 \mathrm{NH}_{4}^{+}+2 \mathrm{OH}^{-} \\
\mathrm{HCO}_{3}^{-}+\mathrm{H}^{+}+2 \mathrm{OH}^{-} \leftrightarrow \mathrm{CO}_{3}^{2-}+2 \mathrm{H}_{2} \mathrm{O}
\end{gathered}
$$

Overall Ureolysis and $\mathrm{CaCO}_{3}$ Precipitation.

$$
\begin{gathered}
\mathrm{NH}_{2} \mathrm{CONH}_{2}+2 \mathrm{H}_{2} \mathrm{O} \Leftrightarrow 2 \mathrm{NH}_{4}^{+}+\mathrm{CO}_{3}^{2-} \\
\mathrm{Ca}^{2+}+\mathrm{CO}_{3}^{2-} \Leftrightarrow \mathrm{CaCO}_{3}(\mathrm{~s})
\end{gathered}
$$

The ability of ureolysis to operate in dark subsurface environments, and the high rates of ureolysis induced $\mathrm{CaCO}_{3}$ precipitation relative to sulfate reduction induced $\mathrm{CaCO}_{3}$ precipitation $(13,18)$, provides a viable mechanism to induce subsurface $\mathrm{CaCO}_{3}$ precipitation and $\mathrm{CO}_{2}$ mineralization. Additionally, the associated reduction in porosity in subsurface environments would reduce the potential of $\mathrm{CO}_{2}$ leakage after injection has ceased. The change in brine chemistry during ureolysis may also enhance the solubilitytrapping capacity of the brine through $\mathrm{pH}$ changes and thus carbonate ion speciation (7). Additionally, microbial biofilms, which are assemblages of microorganism attached to a surface, have shown remarkable resilience to $\mathrm{SC}-\mathrm{CO}_{2}$. This suggests microorganisms in a biofilm form may offer physical, chemical, and biological mechanism to enhance CCS under high pressure during and after injection of $\mathrm{SC}-\mathrm{CO}_{2}(4,5)$ (Figure 1).

Here the effect of bacterially induced ureolysis on $\mathrm{CaCO}_{3}$ precipitation was investigated for a range of fixed initial $\mathrm{CO}_{2}$ headspace pressures and urea concentrations in synthetic brine mimicking the Powder River Basin in Wyoming, a prospective $\mathrm{CO}_{2}$ injection site in the western U.S. (20). Lower than reservoir pressure conditions are considered in this study in order determine the general relationship between ureolysis, mineral formation, and carbonate sources, as well as to ensure the applicability of modeling results, for which accurate thermodynamic data exists.

\section{Experimental Methods}

Experimental Setup. Batch $\mathrm{CO}_{2}$ precipitation microcosms were prepared in sterile $35 \mathrm{~mL}$ serum bottles in a laminar flow hood. Each microcosm included $20 \mathrm{~mL}$ of a synthetic brine (SB) with approximately $5 \mathrm{~g} \mathrm{~L}^{-1}$ total dissolved solids (TDS), mimicking the ionic ratios present in the proposed Powder River Basin $\mathrm{CO}_{2}$ injection site (20). Specific inorganic constituents of the SB are shown in the Supporting Information (SI) Table 1. Three SBs were produced with different

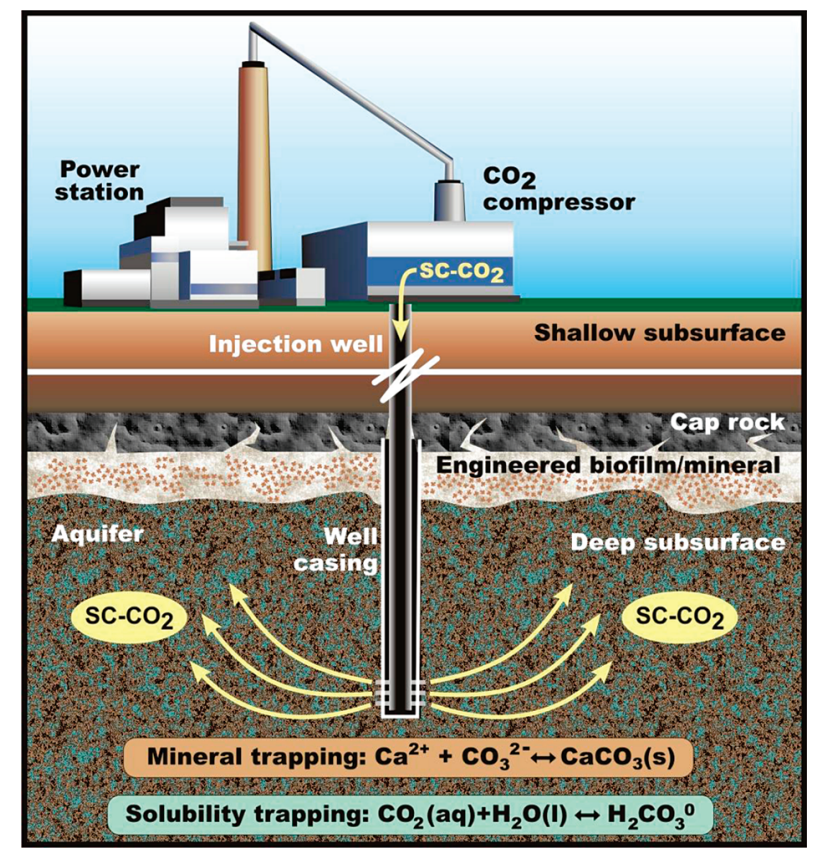

FIGURE 1. Schematic representation of microbially enhanced carbon capture and storage.

urea $\left[\left(\mathrm{NH}_{2}\right)_{2} \mathrm{CO}\right]$ concentrations of 1,5 , or $20 \mathrm{~g} \mathrm{~L}^{-1}$, to simulate the addition of varying concentrations of urea to the aquifer. Test and control SB microcosms were prepared. Test SB microcosms included the ureolytic organism Sporosarcina pasteurii (ATCC 11859, gram-positive, spore-forming, urease positive), known to induce $\mathrm{CaCO}_{3}$ precipitation $(12,17,19)$. Spore forming bacilli have been shown to be resistant to high pressures and the exposure to $\mathrm{SC}-\mathrm{CO}_{2}(4,5,21)$. Biotic control experiments included the nonureolytic gram-positive bacterium Bacillus subtilis strain 186 (ATCC 23857). Abiotic control experiments included just the SB with no bacterial amendment. The headspace $\left(15 \mathrm{~cm}^{3}\right)$ of each vial was then purged with $0.2 \mu \mathrm{m}$ filter sterilized $99 \% \delta^{13} \mathrm{C}-\mathrm{CO}_{2}$ (Cambridge Isotope Laboratories, $\mathrm{MA}$ ) for $1 \mathrm{~min}$, and final headspace $\mathrm{p}\left(\mathrm{CO}_{2}\right)$ of $1,1.35$, and 1.7 atm were attained by measurement with a headspace pressure gauge. A set of microcosms was also retained with an atmospheric pressure air headspace $\left[390 \mathrm{ppm} \mathrm{CO}_{2}(\mathrm{~g})\right.$ at $1 \mathrm{~atm}=0.00039$ atm $\left.\mathrm{p}\left(\mathrm{CO}_{2}\right)\right]$. The microcosms were incubated at $22^{\circ} \mathrm{C}$ on a shaker at $100 \mathrm{rpm}$ for 8 days. While headspace pressures are far lower than expected during deep subsurface $\mathrm{SC}-\mathrm{CO}_{2}$ injection ( $>73 \mathrm{~atm}$ ) (8), these microcosms allow investigation of the general relationship of $\mathrm{p}\left(\mathrm{CO}_{2}\right)$ and ureolysis on carbonate speciation. Additionally, even in deep subsurface brines the $\mathrm{p}\left(\mathrm{CO}_{2}\right)$ will likely vary significantly due to the advective and diffusive transport of $\mathrm{CO}_{2}$ from the injection point over time (22). The SB was characterized for $\mathrm{pH}$, dissolved $\mathrm{Ca}$, and $\mathrm{NH}_{4}{ }^{+}$ immediately after inoculation and headspace adjustment [time $(t)=0, t_{0}$ ], and again after 8 days $\left(t_{8}\right)$ (See SI). At the termination of the experiments any $\mathrm{CaCO}_{3}$ precipitates formed in the microcosms were characterized by X-ray diffraction system (XRD) and analyzed for $\delta^{13} \mathrm{C}$ (SI, eq 1).

Speciation and Saturation Modeling. PHREEQC (23) was used to model inorganic carbon speciation and carbonate mineral saturation in microcosm experiments simulating $\mathrm{CO}_{2}$ injection into the Powder River Basin brine with $\mathrm{p}\left(\mathrm{CO}_{2}\right)$ of $0.00039,1$, and 1.7 atm. All calculations were carried out at $25{ }^{\circ} \mathrm{C}$ and used the MINTEQ database (24), to which the thermodynamic constants for urea was added (25) (see SI). PHREEQC calculates the saturation index $(S)$ of the reacting solution with respect to calcite according to 


$$
S_{\text {calcite }}=\log \frac{\left\{\mathrm{Ca}^{2+}\right\}\left\{\mathrm{CO}_{3}^{2-}\right\}}{K_{\mathrm{SO}}}
$$

where $\left\{\mathrm{Ca}^{2+}\right\}$ and $\left\{\mathrm{CO}_{3}{ }^{2-}\right\}$ are the activities of dissolved $\mathrm{Ca}^{2+}$ and $\mathrm{CO}_{3}{ }^{2-}$, and $K_{\mathrm{so}}$ is the equilibrium calcite solubility product (7).

\section{Results and Discussion}

Synthetic Brine Chemistry. At $\mathrm{t}_{0}$, the biotic test (S. pasteurii), biotic control (B. subtilis), and abiotic control experiments under different $\mathrm{p}\left(\mathrm{CO}_{2}\right)$ and initial urea concentrations exhibited starting chemistries consistent with the SB (SI Table 1), with dissolved Ca concentrations of $\sim 17 \mathrm{mM}$ (Figure 2; SI, Table 2). $\mathrm{NH}_{4}{ }^{+}$concentrations were $\sim 0.4 \mathrm{mM}$, likely due to some limited abiotic urea hydrolysis. The initial $\mathrm{pH}$ of the SB with $\mathrm{p}\left(\mathrm{CO}_{2}\right)$ of 0.00039 atm was $\sim 6$, with lower $\mathrm{pH}$ (between 4 and 5) exhibited in the SB with higher $\mathrm{p}\left(\mathrm{CO}_{2}\right)(1$ to $1.7 \mathrm{~atm}$ ), consistent with a higher concentration of protons liberated from the disassociation of carbonic acid at higher $\mathrm{p}\left(\mathrm{CO}_{2}\right)$ (Figure 2; SI, Table 2) (7). The SB at $t_{0}$ was undersaturated with respect to calcite at all $\mathrm{p}\left(\mathrm{CO}_{2}\right)$. The predicted calcite saturation index $\left(S_{\text {calcite }}\right)$ decreased from approximately -1 to -4 with $\mathrm{p}\left(\mathrm{CO}_{2}\right)$ increasing from 0.00039 to 1.7 atm (Figure 3).

After 8 days $\left(t_{8}\right)$, biotic control and abiotic control experiments under different $\mathrm{p}\left(\mathrm{CO}_{2}\right)$ and initial urea concentrations demonstrated very little, if any, $\mathrm{NH}_{4}{ }^{+}$production associated with some limited abiotic urea hydrolysis, but the $\mathrm{pH}$ remained largely unchanged (Supporting Information, Table 2). Dissolved Ca concentrations remained unchanged relative to $t_{0}$, indicating no $\mathrm{CaCO}_{3}$ precipitation in biotic and abiotic control experiments, consistent with the unchanged and undersaturated solution from $t_{0}$. This would be expected with the biotic control inoculated with the non ureolytic organism, B. subtilis, or with the abiotic control without bacterial amendment, as has been observed previously $(12,17,18,26)$.

Conversely, in the biotic test experiments, $\mathrm{NH}_{4}^{+}$concentrations increased, consistent with the hydrolysis of urea by $S$. pasteurii $(12,17,27,28)$. All available urea was hydrolyzed in the $1 \mathrm{~g} \mathrm{~L}^{-1}, 5 \mathrm{~g} \mathrm{~L}^{-1}$, and $20 \mathrm{~g} \mathrm{~L}^{-1}$ experiments, under different $\mathrm{p}\left(\mathrm{CO}_{2}\right)$, which is consistent with previous studies using up to $20 \mathrm{~g} \mathrm{~L}^{-1}(12,16,26,28)$. The $\mathrm{pH}$ also increased in the $S$. pasteurii inoculated experiments, with relative increases in $\mathrm{pH}$ during the experiments proportional to the amount of urea hydrolyzed, and thus proportional to the initial urea concentrations (Figure 2).

Calcium Carbonate Precipitation in Synthetic Brine at Different $\mathbf{p}\left(\mathbf{C O}_{2}\right)$. Dissolved calcium concentrations decreased by between 97 and $100 \%$ in the biotic experiments with $\mathrm{p}\left(\mathrm{CO}_{2}\right)$ of $1,1.3$, and $1.7 \mathrm{~atm}$ and with 5 or $20 \mathrm{~g} \mathrm{~L}^{-1}$ urea (Figure 2; SI, Table 2). Dissolved Ca reductions were slightly lower, at between 87 and $98 \%$ in the biotic experiments with $\mathrm{p}\left(\mathrm{CO}_{2}\right)$ of $0.00039 \mathrm{~atm}$ and 5 or $20 \mathrm{~g} \mathrm{~L}^{-1}$ urea. This was consistent with the precipitation of up to $17 \mathrm{mM} \mathrm{CaCO}_{3}$ (Figure 3). Biotic test experiments with $1 \mathrm{~g} \mathrm{~L}^{-1}$ urea exhibited only a slight decrease in dissolved $\mathrm{Ca}$ at elevated $\mathrm{p}\left(\mathrm{CO}_{2}\right)$ (Figure 2; SI, Table 2) but significant reduction in dissolved $\mathrm{Ca}$ at $0.00039 \mathrm{~atm}$. This precipitation of $\mathrm{CaCO}_{3}$ in the 0.00039 atm treatments is explained by the initially higher saturation index compared to the treatments with higher initial $\mathrm{p}\left(\mathrm{CO}_{2}\right)$ (Figure 3).

XRD analysis confirmed the $\mathrm{CaCO}_{3}$ polymorph precipitated was calcite, although small amounts of vaterite and aragonite were morphologically observable by scanning electron microscopy (SEM) (data not shown).

Inorganic Carbon Speciation in $\mathrm{CaCO}_{3}$ and Artificial Brine. $\delta^{13} \mathrm{C}-\mathrm{CaCO}_{3}$ was used to discriminate the origin and proportion of carbonate ions in precipitated calcite under
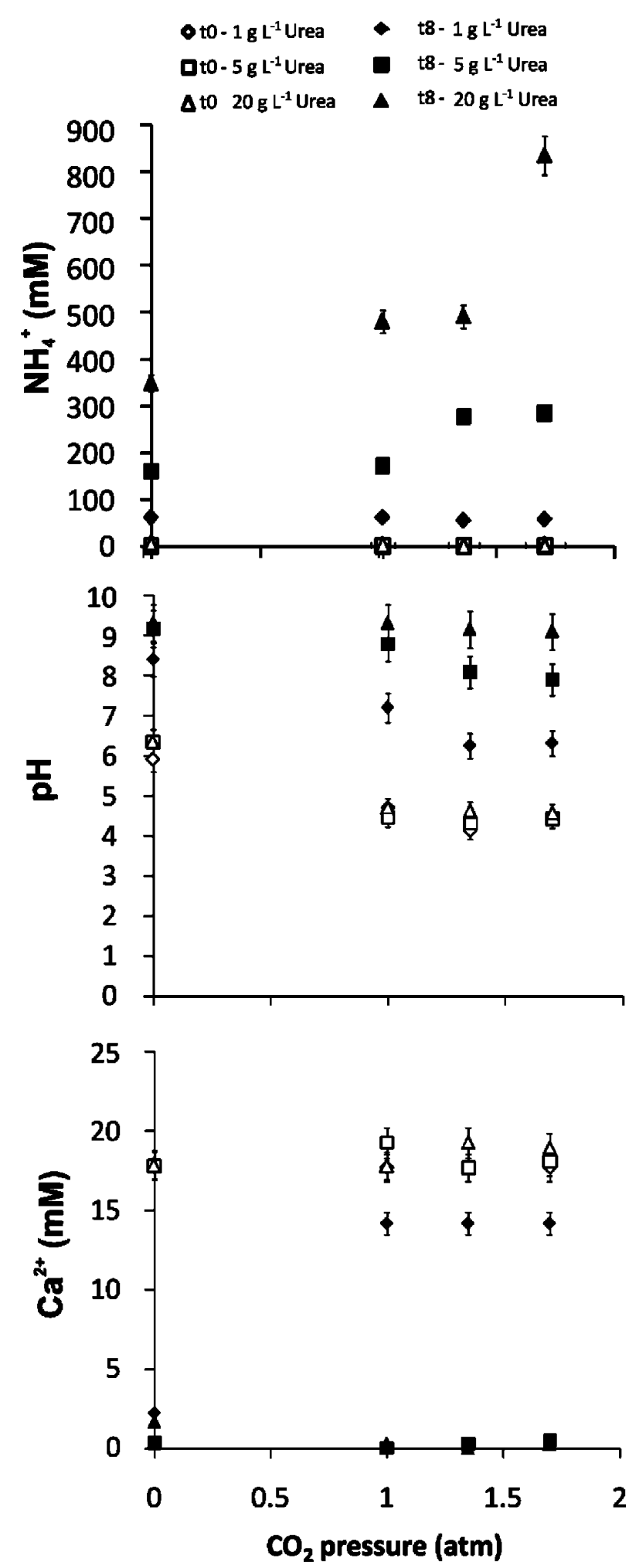

FIGURE 2. Synthetic brine ammonium $\left(\mathrm{NH}_{4}{ }^{+}\right)$concentration, $\mathrm{pH}$, and $\mathrm{Ca}^{2+}$ concentration in $\mathrm{CO}_{2}$ biomineralization experiments inoculated with Sporosarcina pasteurii, at varying $\mathrm{CO}_{2}(\mathrm{~g})$ headspace pressures and urea concentrations at time $t_{0}$ ( 0 days) and $t_{8}$ ( 8 days). Error bars smaller than symbol if not visible.

different $\mathrm{p}\left(\mathrm{CO}_{2}\right)$ and urea concentrations (SI, Table 3). Urea and ${ }^{13} \mathrm{C}-\mathrm{CO}_{2}(\mathrm{~g})$ provide two potential carbonate ion sources in the microcosm experiments simulating $\mathrm{CO}_{2}$ injection into the Powder River Basin brine aquifer. The ${ }^{13} \mathrm{C}-\mathrm{CO}_{2}$ had a $\delta^{13} \mathrm{C}$ of $+89000 \%$ o $\left(=99 \%{ }^{13} \mathrm{C}-\mathrm{CO}_{2}\right.$. see SI, eq 2 for details), and the urea used exhibited a $\delta^{13} \mathrm{C}$ of $-40.6 \%$. The SB also 

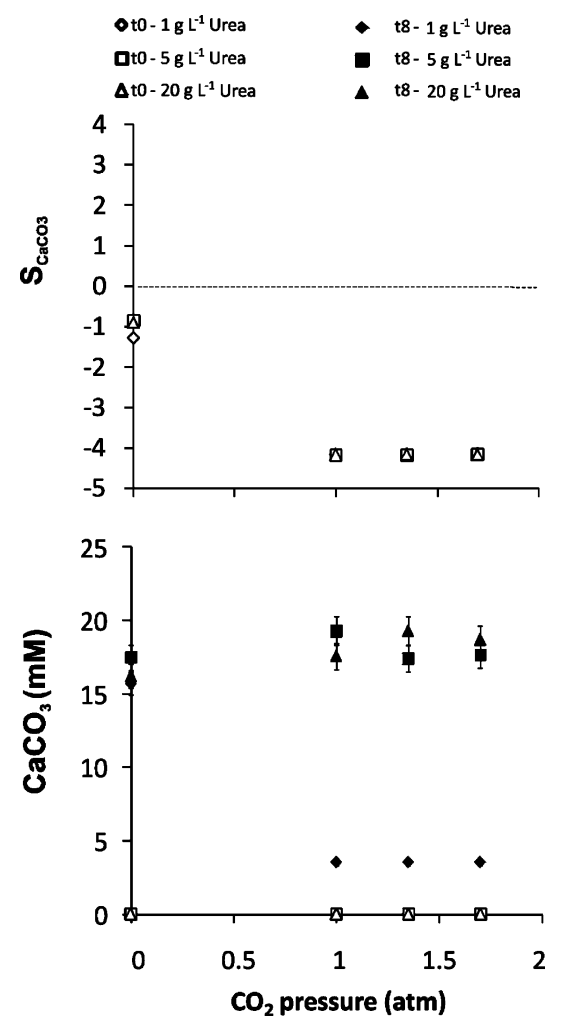

FIGURE 3. Synthetic brine $\mathrm{CaCO}_{3}$ (calcite) saturation index $\left(S_{\mathrm{CaCO}_{03}}\right)$ at time $t_{0}$ and mass of $\mathrm{CaCO}_{3}$ precipitated $(\mathrm{mM})$ at time $t_{0}$ and $t_{8}\left(8\right.$ days) at varying $\mathrm{CO}_{2}(g)$ headspace pressures and urea concentrations in $\mathrm{CO}_{2}$ biomineralization experiments inoculated with Sporosarcina pasteurii.

contained $0.25 \mathrm{mM} \mathrm{MgCO}_{3}$ with a $\delta^{13} \mathrm{C}$ of $-8.0 \%$. The $\delta^{13} \mathrm{C}-\mathrm{CaCO}_{3}$ of calcite precipitated from the $1,1.3$, and 1.7 atm $\mathrm{p}\left(\mathrm{CO}_{2}\right)$ microcosms ranged from +4.0 to $+57877 \%$, indicating the precipitated calcite was heavily enriched with carbon originally from the ${ }^{13} \mathrm{C}-\mathrm{CO}_{2}$ (g) over the brine (SI, Table 3).

Natural isotopic equilibrium fractionation can be expected during $\mathrm{CO}_{2}(\mathrm{~g})$ dissolution and disassociation, between $\mathrm{CO}_{2}(\mathrm{~g})$ and dissolved bicarbonate, but this will only account for an increase of +7.9 to $+8.4 \%$ o (29). Calcite precipitated with 0.00039 atm $\mathrm{p}\left(\mathrm{CO}_{2}\right)$ exhibited $\delta^{13} \mathrm{C}-\mathrm{CaCO}_{3}$ of +1.1 , reflecting the natural abundance of ${ }^{13} \mathrm{C}$ on Earth, and consistent with most natural calcites precipitated at ambient $\mathrm{p}\left(\mathrm{CO}_{2}\right)$ (29). These data demonstrate that the ${ }^{13} \mathrm{C}$ as a $\%$ of total $\mathrm{C}$ in $\mathrm{CaCO}_{3}$ increased with increasing $\mathrm{p}\left(\mathrm{CO}_{2}\right)$ for each of the urea concentrations (Figure 4a). Additionally, higher urea concentrations increased the proportion of ${ }^{13} \mathrm{C}$ incorporated into $\mathrm{CaCO}_{3}$ at a given $\mathrm{p}\left(\mathrm{CO}_{2}\right)$, from an average of $8.3 \%$ at $1 \mathrm{~g} \mathrm{~L}^{-1}$ to $31 \%$ at $5 \mathrm{~g} \mathrm{~L}^{-1}$ and $37 \%$ at $20 \mathrm{~g} \mathrm{~L}^{-1}$ (Figure $4 \mathrm{a}$ ). A maximum of $65 \%$ of carbon from the original atmosphere of the microcosm was precipitated in calcite. It can be seen from the stoichiometry of the ureolysis reaction (eqs 10 and 11), that no net precipitation of $\mathrm{CO}_{2}(\mathrm{~g})$ in $\mathrm{CaCO}_{3}$ occurred during urea hydrolysis-induced mineral-trapping. However, the increase in $\delta^{13} \mathrm{C}-\mathrm{CaCO}_{3}$ with increasing $\mathrm{p}\left(\mathrm{CO}_{2}\right)$ and at higher urea concentrations with equivalent $\mathrm{p}\left(\mathrm{CO}_{2}\right)$ demonstrates that (i) ureolysis enhances the proportion of carbonate ions precipitated in $\mathrm{CaCO}_{3}$ that are from the originally gaseous $\mathrm{CO}_{2}$ and (ii) there is a higher proportion of carbonate ions from the originally gaseous ${ }^{13} \mathrm{CO}_{2}$ relative to carbonate ions derived from urea dissolved in the brine. Previous studies suggest that the $\mathrm{C}$ isotopes of dissolved carbonate and $\mathrm{CO}_{2}(\mathrm{~g})$ equilibrate within 12 to $24 \mathrm{~h}(30,31)$. This shows that extensive transport of ${ }^{13} \mathrm{C}$ from the gas phase to the aqueous phase would occur without a net flux of carbon from the gas phase.
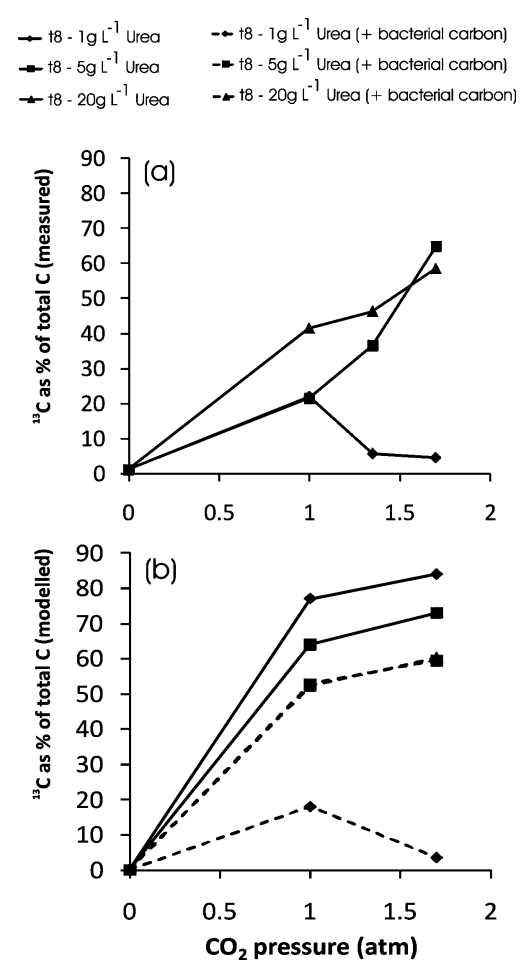

FIGURE 4. (a) Measured and (b) modeled ${ }^{13} \mathrm{C}$ as a percentage of total $\mathrm{C}$ in precipitated $\mathrm{CaCO}_{3}$ in $\mathrm{CO}_{2}$ biomineralization experiments inoculated with Sporosarcina pasteurii by $t_{8}$ (8 days). Dashed lines represent models which include $50 \mathrm{mg}$ $\mathrm{L}^{-1}$ bacterial organic carbon by $t_{8}$ ( 8 days).

Therefore, the $\mathrm{CO}_{2}(\mathrm{~g})$ concentration in the gas phase was unlikely to be lowered by up to $65 \%$, as might be suggested from the isotope data. Thermodynamic modeling on PHREEQC (23) allowed testing of the validity of the experimental results, in order to examine the speciation of carbon from $\mathrm{CO}_{2}(\mathrm{~g})$ to aqueous species during ureolysis induced carbonate precipitation in brine.

The modeled $\mathrm{pH}$ and mass of calcite precipitated by $t_{8}$ (SI, Table 3) is largely in agreement with the experimental values. The actual amount of Ca scavenged in experiments with $1 \mathrm{~g} \mathrm{~L}^{-1}$ urea is slightly larger than in the calculations. Possibly, this may reflect Ca adsorption to bacterial surfaces in the experiments, as observed previously (32), an effect that has not been included in the model. From PHREEQC calculations, the ${ }^{13} \mathrm{C}$ content of the precipitated calcite was predicted based on the assumption that the equilibration of $\mathrm{C}$ isotopes in solution and gas phase occurred at rates much faster than the calcite precipitation. Previous studies demonstrate precipitation occurs over $2-3$ days (12), versus equilibration of $\mathrm{C}$ isotopes in solution and gas phase which occurs within 12 to $24 \mathrm{~h}(30,31)$, so the assumption is valid. For each step of urea hydrolysis, the sequence of the calculation was (i) addition of $1 \mathrm{mM}$ carbonate with $\delta^{13} C=$ $0 \%$ o to the solution to reflect urea hydrolysis; (ii) equilibration of the $\mathrm{C}$ isotopes of the solution and the gas phase [initial $\delta^{13} \mathrm{CO}_{2}=89000 \%$ o] based on mass balance; (iii) when calcite precipitated from supersaturated solutions, its $C$ isotope composition reflected that of the dissolved carbonate. At the end of urea hydrolysis, when $100 \mathrm{mM}$ of urea had been hydrolyzed, the final $\mathrm{C}$ isotope composition of the calcite was calculated from the mass and isotope composition of the solid precipitated at each step.

The modeled $\mathrm{C}$ isotope compositions are more positive than those determined experimentally, especially for the experiments with $1 \mathrm{~g} \mathrm{~L}^{-1}$ urea (Figure 4b; SI, Table 3). The difference between measured and predicted values correlates with the amount of calcite precipitated in the experiments, 
where experiments precipitating only a small mass of calcite display very light isotope compositions relative to that measured. A likely explanation for this is that all isotope analyses are influenced by carbon contamination from the bacterial biomass, that accumulated on the crystal surfaces during filtration, or within the crystals, as demonstrated previously (12). Such organic carbon is isotopically lighter with respect to carbon, therefore exhibiting a lower $\delta^{13} \mathrm{C}$. PHREEQC modeling suggested the discrepancy between measured and modeled $\delta^{13} \mathrm{C}$ values could be accounted for by the mass of bacterial carbon in the experiments $(50 \mathrm{mg}$ $\mathrm{L}^{-1}$ ) (Figure 4b; SI, Table 3). However, it is unclear if such an extensive digestion of organic material by the standard phosphoric acid digestion used during $\mathrm{C}$ isotope analysis of carbonate is possible (33).

In addition, in all calculations outlined here, it was assumed that dissolved carbonate and $\mathrm{CO}_{2}(\mathrm{~g})$ are at isotopic equilibrium. It is possible that this is not the case and that $\mathrm{C}$ isotopes of dissolved carbonate only equilibrated partly with the atmosphere during the initial calcite precipitation. Because the hydrolysis of urea is completed faster in the $1 \mathrm{~g}$ $\mathrm{L}^{-1}$ experiments, such an effect would influence results from these experiments the most. Indeed, the modeled values differ mostly from the measured values for the $1 \mathrm{~g} \mathrm{~L}^{-1}$ experiments. However, without detailed knowledge of the kinetics of $\mathrm{C}$ isotope exchange and urea hydrolysis, we cannot quantify the effect of partial isotope equilibration. Nevertheless, the combination of a feasible mass of organic carbon in the experiments, and partial equilibration of organic carbon and dissolved carbonate and $\mathrm{CO}_{2}(\mathrm{~g})$ appear to account for the observed $\delta^{13} \mathrm{C}$ of the $\mathrm{CaCO}_{3}$.

Evolution of Brine Chemistry and Carbonate Speciation As a Function of Ureolysis Progress. The capacity of the brine for carbonate ions and the precipitation of $\mathrm{CaCO}_{3}$ is controlled by the complex interplay of carbonate equilibrium and $\mathrm{pH}$ (7). We therefore evaluated the detailed evolution of the brine chemistry and carbonate precipitation using PHREEQC (23) in order to elucidate the detailed changes in carbonate speciation and fluxes between the gas, solid, and solution phases. This was undertaken for the Powder River SB chemistry used in the microcosm experiments, including $17 \mathrm{mM}$ Ca (SI, Table 1) at 0.00039, 1.0, and $1.7 \mathrm{~atm} \mathrm{p}\left(\mathrm{CO}_{2}\right)$. This was also undertaken for other theoretical groundwater, based upon the chemistry of the Powder River Basin, but including Ca concentrations of $2 \mathrm{mM}$, equivalent to many common groundwater compositions $(34,35)$ and $125 \mathrm{mM}$ Ca, equivalent to many oil field brines $(36,37)$ (Figure 5; SI, Figure 1).

The modeling for solutions including $17 \mathrm{mM}$ Ca demonstrate that after equilibration of the groundwater solutions with the headspace $\mathrm{CO}_{2}(\mathrm{~g})$, for $\mathrm{p}\left(\mathrm{CO}_{2}\right)$ above atmospheric pressure, (i) ureolysis increases $\mathrm{pH}$, via the net production of hydroxide ions and consumption of protons (eq 8). (ii) Once supersaturated, $\mathrm{CaCO}_{3}$ precipitates, and the degree of ureolysis required for the induction of precipitation is greater at higher initial $\mathrm{p}\left(\mathrm{CO}_{2}\right)$ because it takes longer for the $\mathrm{pH}$ to increase to the point where the solution is saturated with respect to calcite. In addition, at higher initial $\mathrm{p}\left(\mathrm{CO}_{2}\right)$, the proportion of carbonate ions precipitated in $\mathrm{CaCO}_{3}$ decreases at a given degree of ureolysis, with a greater proportion remaining as aqueous carbonate ions $\left[\mathrm{CO}_{3}(\mathrm{aq})\right]$. (iii) Headspace $\mathrm{p}\left(\mathrm{CO}_{2}\right)$ decreases, as long as ureolysis continues and $\mathrm{pH}$ is increasing, as the carbonate ion capacity and aqueous carbonate ion concentration increases in response to the increasing $\mathrm{pH}$. Here, at higher initial $\mathrm{p}\left(\mathrm{CO}_{2}\right)$, the mass of $\mathrm{CO}_{2}$ dissolving into the groundwater solutions, and thus the concentration of $\mathrm{CO}_{3}(\mathrm{aq})$, increases, at a given degree of ureolysis. This reduced the headspace concentration of $\mathrm{CO}_{2}$ by up to $32 \mathrm{mM}$ per $100 \mathrm{mM}$ urea hydrolyzed (Figure 5). Modeling results for calcium concentrations of $2 \mathrm{mM}$ and

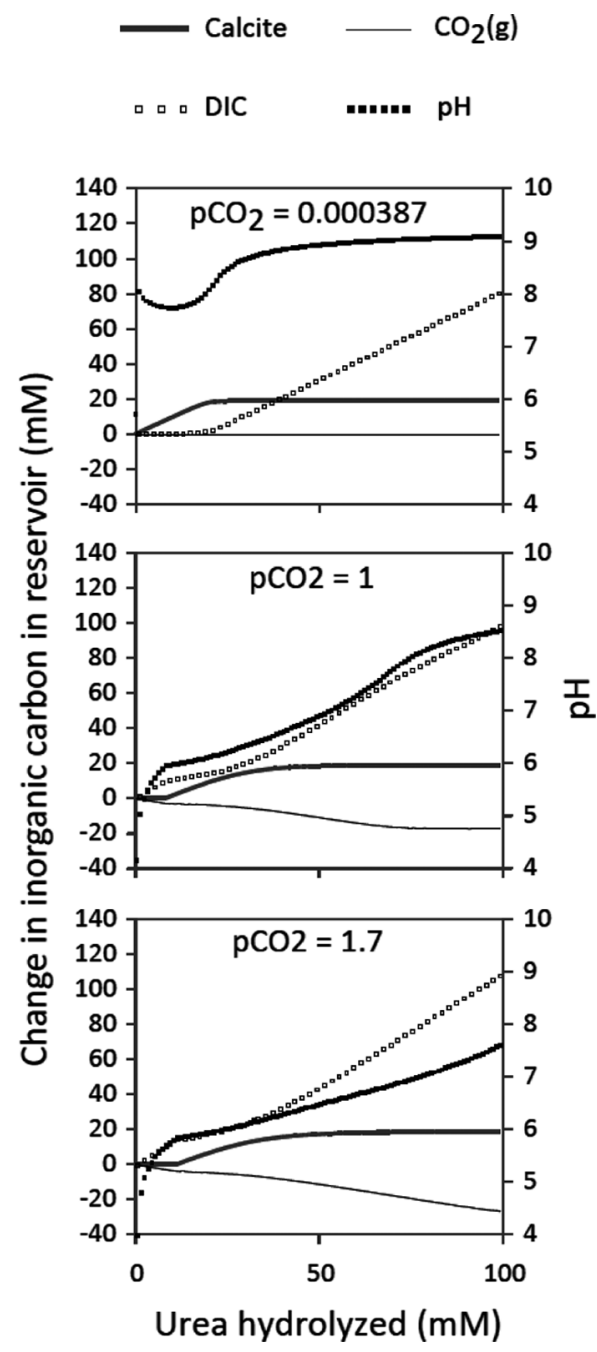

FIGURE 5. Modeled evolution of Powder River Basin brine chemistry and carbonate speciation as a function of ureolysis progress at variable $\mathrm{p}\left(\mathrm{CO}_{2}\right)$ in atm for a brine containing $17 \mathrm{mM}$ of dissolved calcium and consistent with that used in the experimental study (SI, Table 1). Dissolved Inorganic Carbon (DIC) represents all dissolved carbonate species.

$125 \mathrm{mM}$ demonstrate the same general trends (SI, Figure 1). However, increased calcium concentrations lower the $\mathrm{pH}$ attained at a given degree of ureolysis due to the precipitation of $\mathrm{CaCO}_{3}$, which results in the liberation of protons during the conversion of $\mathrm{HCO}_{3}{ }^{-}$to $\mathrm{CO}_{3}{ }^{2-}$ (eqs 4 and 11). Therefore at higher calcium concentrations, a greater mass of urea has to be hydrolyzed to attain a particular $\mathrm{pH}$ and DIC concentration, via the flux of $\mathrm{CO}_{2}(\mathrm{~g})$ into solution as the carbonate ion capacity and aqueous carbonate ion concentration increases in response to the increasing $\mathrm{pH}$.

The Potential of Microbially Enhanced CCS. The data presented here suggest the potential of microbial ureolysis to increase the rate of mineral-formation and enhance solubility-trapping of $\mathrm{CO}_{2}$ injected into brine aquifers. This occurs primarily via the $\mathrm{pH}$ increase induced by ureolysis which induces carbonate precipitation and increases the carbonate capacity of the SB (7).

While $\mathrm{CaCO}_{3}$ is precipitated, the moles of calcite precipitated were equal to or less than the moles of urea derived carbonate ions. Thus, no net precipitation of $\mathrm{CO}_{2}(\mathrm{~g})$ in $\mathrm{CaCO}_{3}$ occurred during urea hydrolysis-induced mineral-trapping. Additionally, the consumption of $\mathrm{Ca}^{2+}$, and the likelihood that this will not be replenished via equilibration because of the concurrent rise in $\mathrm{pH}$, may reduce the magnitude of natural carbonation in the aquifer. However, the precipitation 
of $\mathrm{CaCO}_{3}$ by ureolysis in the brine provides a number of distinct engineering advantages. First, ureolytic organisms appear to be ubiquitous in surface and subsurface soils $(19,38)$ and $S$. pasteurii has been shown by us to be ureolytically active at pressures and temperatures relevant to geologic carbon sequestration scenarios $(P>89$ bar, $T>$ $\left.32{ }^{\circ} \mathrm{C}\right)(39)$. Thus engineering solutions could likely rely on the stimulation of native organisms to induce $\mathrm{CaCO}_{3}$ precipitation. Second, wastewater provides a potential supply of waste urea. If wastewater urea sources can be utilized in this process, it may provide the simultaneous and advantageous degradation of urea waste, and thus a reduction in labile earth surface carbon, and the mineral- and solubilitytrapping of injected $\mathrm{CO}_{2}$. The annual volume of wastewater was $1347 \mathrm{~km}^{3} \mathrm{yr}^{-1}$ in Europe, North America and Asia in 1995 (40). Wastewater commonly includes urea concentrations of $20 \mathrm{~g} \mathrm{~L}^{-1}$ (333 mM) (41), which is more than required to maintain calcite supersaturation in groundwater with chemistries like those of the Powder River Basin, and to precipitate out all available dissolved Ca even in concentrated oilfield brines with Ca concentrations of $125 \mathrm{mM}$ or more (SI, Figure 1). Third, the precipitation of $\mathrm{CaCO}_{3}$ in the subsurface provides a means to decrease formation porosity and reduce the potential of $\mathrm{CO}_{2}$ leakage. For example, subsurface ureolysis induced carbonate precipitation has been investigated for permeability reduction for enhanced oil recovery and radionuclide contaminant sequestration (16).

The main potential limitation of microbially enhanced CCS is the ability of microorganisms to withstand high pressure and $\mathrm{SC}-\mathrm{CO}_{2}$. Planktonic cells (free floating) show limited resistance to $\mathrm{SC}-\mathrm{CO}_{2}$. Twenty-two tested vegetative species of microorganisms reported in the literature were completely deactivated at some combination of pressure and temperature in the presence of $\mathrm{SC}-\mathrm{CO}_{2}$ (21). However, biofilms, which are microorganism assemblages firmly attached to a surface, appear to exhibit a higher resistance to $\mathrm{SC}-\mathrm{CO}_{2}(4,5)$. For example, a $19 \mathrm{~min}$ exposure to $35^{\circ} \mathrm{C}$, 136 atm $\mathrm{SC}-\mathrm{CO}_{2}$ resulted in a $3 \log _{10}$ viability reduction of planktonic Bacillus mojavensis cells, but resulted in only a $1 \log _{10}$ reduction in viable cell numbers from biofilm cultures. It is hypothesized that the small reduction in the viability of biofilm microorganisms reflects the protective role of the biofilm extracellular polymeric substances $(4,5)$. The resilience of microorganisms in biofilm states, to high pressure gaseous and $\mathrm{SC}-\mathrm{CO}_{2}$ suggests microbially enhanced mineraltrapping and solubility-trapping of $\mathrm{CO}_{2}$ during CCS may be effectively used. In conclusion, a microbial ureolysis based approach appears to offer potential for enhancing CCS by (i) increasing the flux of gas into the brine, and the capacity of brine for carbonate ions, and (ii) the formation of carbonate minerals, potentially reducing formation porosity and the potential of $\mathrm{CO}_{2}$ leakage to the surface. The apparent resilience of biofilm-organisms to $\mathrm{SC}-\mathrm{CO}_{2}$ suggests these and other micobially mediated processes may offer the ability to enhance the capacity and rates of $\mathrm{CO}_{2}$ trapping.

\section{Acknowledgments}

Funding was provided from the U.S. Department of Energy (DOE) Zero Emissions Research Technology Center (ZERT), Award No. DE-FC26-04NT42262 and DOE EPSCoR Award No. DE-FG02-08ER46527 as well as a European Union (EU) Marie Curie Postdoctoral Fellowship to ACM. Support for the Environmental and Biofilm Mass Spectrometry Facility through DURIP, Contract Number: W911NF0510255 and the MSU Thermal Biology Institute from the NASA Exobiology Program Project NAG5-8807 is acknowledged.

\section{Supporting Information Available}

1. Details regarding the experimental methods for the microcosm experiments, 2. Information on experimental details and calculations regarding the ${ }^{13} \mathrm{C}$ fraction in the precipitated carbonates, 3. Information regarding the geochemical modeling. A detailed explanation on how the amount of bacterial organic carbon in filtered $\mathrm{CaCO}_{3}$ samples was determined. Three tables and one additional figure are also included. This material is available free of charge via the Internet at http://pubs.acs.org.

\section{Literature Cited}

(1) Zakkour, P.; Haines, M. Permitting issues for $\mathrm{CO}_{2}$ capture, transport and geological storage: A review of Europe, USA, Canada and Australia. Int. J. Greenhouse Gas Control 2007, 1, 94-100.

(2) White, C. M.; Strazisar, B. R.; Granite, E. J.; Hoffman, J. S.; Pennline, H. W. Separation and capture of $\mathrm{CO}_{2}$ from large stationary sources and sequestration in geological formationsCoalbeds and deep saline aquifers. J. Air Waste Manage. Assoc. 2003, 53 (6), 645-715.

(3) Metz, B.; Davidson, O.; de Coninck, H.; Loos, M.; Meyer, L. (Eds.). Carbon Dioxide Capture and Storage. Summary for Policy Makers and Technical Summary. IPCC, Geneva, Switzerland, pp 53.

(4) Mitchell, A. C.; Phillips, A.; Hiebert, R.; Gerlach, R.; Spangler, L.; Cunningham, A. B. Biofilm enhanced subsurface sequestration of supercritical $\mathrm{CO}_{2}$. Int. J. Greenhouse Gas Control 2009, 3, 90-99.

(5) Mitchell, A. C.; Phillips, A. J.; Hamilton, M. A.; Gerlach, R.; Hollis, W. K.; Kaszuba, J. P.; Cunningham, A. B. Resilience of planktonic and biofilm cultures to supercritical $\mathrm{CO}_{2}$. J. Supercrit. Fluids 2009, 47, 318-325.

(6) Gilfillan, S. M. V.; Lollar, B. S.; Holland, G.; Blagburn, D.; Stevens, S.; Schoell, M.; Cassidy, M.; Ding, Z. J.; Zhou, Z.; LacrampeCouloume, G.; Ballentine, C. J. Solubility trapping in formation water as dominant $\mathrm{CO}_{2}$ sink in natural gas fields. Nature 2009, 458 (7238), 614-618.

(7) Stumm, W.; Morgan, J. J., Aquatic Chemistry, 3rd ed.; John Wiley \& Sons: New York, 1996; p 1040.

(8) Kaszuba, J. P.; Janecky, D. R., Geochemical impacts of sequesting carbon dioxide in brine aquifers. In The Science and Technology of Carbon Sequestration; McPherson, J. M.; Sundquist, E., Eds.; American Geophysical Union Monograph: Washington, DC, 2010; in press.

(9) Gunter, W. D.; Perkins, E. H.; Hutcheon, I. Aquifer disposal of acid gases: modelling of water-rock reactions for trapping of acid wastes. Appl. Geochem. 2000, 15 (8), 1085-1095.

(10) Kaszuba, J. P.; Janecky, D. R.; Snow, M. G. Experimental evaluation of mixed fluid reactions between supercritical carbon dioxide and $\mathrm{NaCl}$ brine: Relevance to the integrity of a geologic carbon repository. Chem. Geol. 2005, 217 (3-4), 277-293.

(11) Schultze-Lam, S.; Fortin, D.; Davis, B. S.; Beveridge, T. J. Mineralization of bacterial surfaces. Chem. Geol. 1996, 132 (14), 171-181.

(12) Mitchell, A. C.; Ferris, F. G. The coprecipitation of Sr into calcite precipitates induced by bacterial ureolysis in artificial groundwater: Temperature and kinetic dependence. Geochim. Cosmochim. Acta 2005, 69 (17), 4199-4210.

(13) Van Lith, Y.; Warthmann, R.; Vasconcelos, C.; McKenzie, J. A. Microbial fossilization in carbonate sediments: A result of the bacterial surface involvement in dolomite precipitation. Sedimentology 2003, 50, 237-245.

(14) Bell, P. E.; Mills, A. L.; Herman, J. S. Biogeochemical conditions favoring magnetite formation during anaerobic iron reduction. Appl. Environ. Microbiol. 1987, 53 (11), 2610-2616.

(15) Ferris, F. G.; Thompson, J. B.; Beveridge, T. J. Modern freshwater microbialites from Kelly lake, British Columbia, Canada. Palaios 1997, 12 (3), 213-219.

(16) Ferris, F. G.; Stehmeier, L. G.; Kantzas, A.; Mourits, F. M. Bacteriogenic mineral plugging. J. Can. Pet. Technol. 1996, 35 (8), 56-61.

(17) Mitchell, A. C.; Ferris, F. G. The Influence of Bacillus pasteurii on the nucleation and growth of calcium carbonate. Geomicrobiol. J. 2006, 23 (3-4), 213-226.

(18) Mitchell, A. C.; Ferris, F. G. Effect of strontium contaminants upon the size and solubility of calcite crystals precipitated by the bacterial hydrolysis of urea. Environ. Sci. Technol. 2006, 40 (3), 1008-1014.

(19) Fujita, Y.; Taylor, J. L.; Gresham, T. L.; Delwiche, M. E.; Colwell, F. S.; McLing, T.; Petzke, L.; Smith, R. W. Stimulation of microbial urea hydrolysis in groundwater to enhance calcite precipitation. Environ. Sci. Technol. 2008, 42, 3025-3032. 
(20) Busby, J. F.; Kimball, B. A.; Downey, J. S.; Peter, K. D. Geochemistry of water in aquifers and confining units of the Northern Great Plains in parts of Montana, North Dakota, South Dakota, and Wyoming, U.S.G.S. Professional Paper 1402-F; U.S. Geological Survey: Washington, DC, 1995; p 146.

(21) Zhang, J.; Davis, T. A.; Matthews, M. A.; Drews, M. J.; LaBerge, M.; An, Y. H. Sterilization using high-pressure carbon dioxide. J. Supercrit. Fluids 2006, 38 (3), 354-372.

(22) Oldenburg, C. M.; Pruess, K.; Benson, S. M. Process Modeling of $\mathrm{CO}_{2}$ injection into natural gas reservoirs for carbon sequestration and enhanced gas recovery. Energy Fuels 2001, 15 (2), 293-298.

(23) Parkhust, D.; Appelo, C. User's Guide to PHREEQC (Version 2)A Computer Program for Speciation, Batch-Reaction, OneDimensional Transport, And Inverse Geochemical Calculations, Water-Resources Investigations Report 99-4259; U.S. Geological Survey: Washington, DC, 1999.

(24) Allison, J. D.; Brown, D. S.; Novo-Gradac, K. J. MINTEQA2/ PRODEFA2-A Geochemical Assessment Model for Environmental Systems: Version 3.0 User's Manual; U.S. Environmental Protection Agency: Washington, DC, 1990.

(25) Stokes, R. Thermodynamics of aqueous urea solutions. Aust. J. Chem. 1967, 20 (10), 2087-2100.

(26) Fujita, Y.; Ferris, F. G.; Lawson, R. D.; Colwell, F. S.; Smith, R. W. Calcium carbonate precipitation by ureolytic subsurface bacteria. Geomicrobiol. J. 2000, 17 (1), 305-318.

(27) Hammes, F.; Boon, N.; de Villiers, J.; Verstraete, W.; Siciliano, S. D. Strain-specific ureolytic microbial calcium carbonate precipitation. Appl. Environ. Microbiol. 2003, 69 (8), 4901-4909.

(28) Warren, L. A.; Maurice, P. A.; Parmar, N.; Ferris, F. G. Microbially mediated calcium carbonate precipitation: Implications for interpreting calcite precipitation and for solid-phase capture of inorganic contaminants. Geomicrobiol. J. 2001, 18 (1), 93115.

(29) Hoefs, J., Stable Isotope Geochemistry; Springer: Berlin, 1973; p 140.

(30) Lesniak, P. M.; Zawidzki, P. Determination of carbon fractionation factor between aqueous carbonate and $\mathrm{CO}_{2}(\mathrm{~g})$ in two-direction isotope equilibration. Chem. Geol. 2006, 231 (3), 203-213.
(31) Zhang, J.; Quay, P. D.; Wilbur, D. O. Carbon isotope fractionation during gas-water exchange and dissolution of $\mathrm{CO}_{2}$. Geochim. Cosmochim. Acta 1995, 59 (1), 107-114.

(32) Ferris, F. G.; Fyfe, W. S.; Beveridge, T. J. Metallic Ion Binding by Bacillus subtilis -Implications for the Fossilization of Microorganisms. Geology 1988, 16 (2), 149-152.

(33) Wierzbowski, H. Effects of pre-treatments and organic matter on oxygen and carbon isotope analyses of skeletal and inorganic calcium carbonate. Int. J. Mass Spectrom. 2007, 268 (1), 16-29.

(34) Nonner, J., Introduction to Hydrogeology; Taylor \& Francis: London, 2002; p 258.

(35) Knobel, L. L.; Bartholomay, R. C.; Cecil, L. D.; Tucker, B. J.; Wegner, S. J., Chemical Constituents in the Dissolved and Suspended Fractions of Ground Water from Selected Sites, Idaho National Engineering Laboratory and Vicinity, Idaho, 1989; U.S. Geological Survey: Washington, DC, 1992; pp 92-51.

(36) Carpenter, A. B.; Trout, M. L.; Pickett, E. E. Preliminary report on origin and chemical evolution of lead-rich and zinc-rich oil field brines in central Mississippi. Econ. Geol. 1974, 69, (8), 11911206.

(37) Richter, B.; Kreitler, C., Geochemical Techniques for Identifying Sources of Ground-Water Salinization; CRC Press: New York, 1993; p 258.

(38) Lloyd, A. B.; Sheaffe, M. J. Urease activity in soils. Plant Soil 1973, 39 (1), 71-80.

(39) Mitchell, A.; Phillips, A.; Kaszuba, J.; Hollis, W.; Cunningham, A.; Gerlach, R. Microbially enhanced carbonate mineralization and the geologic containment of $\mathrm{CO}_{2}$. Geochim. Cosmochim. Acta 2008, 72 (12), A636.

(40) World Water Assessment Programme, Water for People: Water for Life - The UN World Water Development Report (The United Nations World Water Development Report); Berghahn Books: Oxford, NY, 2003.

(41) Rittstieg, K.; Robra, K. H.; Somitsch, W. Aerobic treatment of a concentrated urea wastewater with simultaneous stripping of ammonia. Appl. Microbiol. Biotechnol. 2001, 56 (5), 820-825.

ES903270W 